\title{
金属間相互作用の増強が鍵となる光誘起結晶相転移と Photosalient効果
}

\author{
北海道大学大学院工学研究院・フロンティア化学教育研究センター 関 朋宏, 伊藤 肇
}

\begin{abstract}
Tomohiro SEKI and Hajime ITO: Photoinduced Crystalline Structure Change and Photosalient Effect through Strengthening Metallophilic Interaction

We report the first photoinduced single-crystal-to-single-crystal (SCSC) phase transition of a gold complex 1 that involves strengthening of intermolecular aurophilic interactions. This is also the first solid state photochromism of gold complexes. Upon UV irradiation, blue-emitting crystals 1B of aryl gold(I) isocyanide complex 1 transform into the weakly yellow-emitting crystals $\mathbf{1 Y}$. $\mathrm{X}$-ray diffraction analyses exhibit that the phase transition proceeds in an SCSC manner. After phase transition from $\mathbf{1 B}$ to $\mathbf{1 Y}$, the intermolecular $\mathrm{Au} \cdots \mathrm{Au}$ separation decreases from 3.5041 (14) to 3.2955 (6) $\AA$, resulting in a red-shifted emission. The photoinduced strengthening of the aurophilic interactions in the excited state initiates the change in the crystal structure from 1B to 1Y. Moreover, crystal 1B showed a photosalient effect: the 1B crystals jump upon irradiation with strong UV light owing to the phase transition into 1Y. The photoinduced strengthening of aurophilic interactions in the crystal generate the sudden mechanical movement of the crystal.
\end{abstract}

\section{1.はじめに}

フォトクロミック分子は, 光照射によって固体やその 溶液の色が変化する分子の総称である.1) アゾベンゼン やジアリールエテンは, 代表的なフォトクロミック分子 であり, 紫外光の照射によって光異性化することで色調 変化を示す. 可視光の照射や温度変化によって逆異性 化が進行する場合には, 色調は可逆的に変化する.フォ トクロミック分子の色調が変化する要因は, 光異性化に 伴い異性体間で分子構造が変化するためである. 同じ分 子でも異性体同士は, 吸収波長が異なるため光異性化に より色調が変化する.

フォトクロミック分子の光異性化は, 一般的に固体中 と比較して溶液中において進行しやすい, その理由は, 溶液中で分子を均一に分散させることで, 照射した光が 系全体の分子を効率良く励起できるためである。また, 溶液中の分子は比較的自由なコンフォメーション変化 が可能なため, 光異性化で重要となる化学結合の変化を 起こしやすいことも要因として挙げられる. 以上の理由 から溶液中で光異性化を示すフォトクロミック分子が 数多く報告されているが, 一方で, 固体状態でも光異性 化が進行する系は少ない.

固体状態でフォトクロミズムが進行する系では, 分子 の光異性化 (分子構造の変化) に伴い, 結晶構造やさま ざまな物性が変化する。このような系の中で最も有名 な研究の1つとして, 入江先生らがNatureに報告したジ アリールエテン結晶の研究が挙げられる (図1).2) ジア

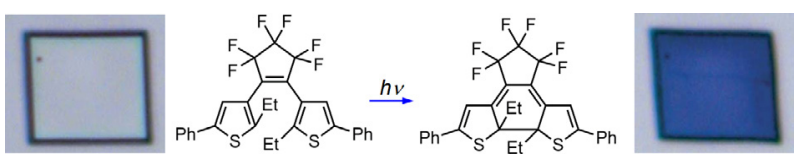

図1 ジアリールエテン誘導体結晶のフォトクロミズ ム. (Photochromism of the crystal of diarylethene derivative.)

リールエテン誘導体の開環体からなる無色の結晶に対し て, $365 \mathrm{~nm}$ の紫外光を照射すると結晶が紫色に着色し, 結晶外形が変形する。これらの変化は, 結晶内でもジア リールエテン分子が閉環体へと光異性化し, さらに結晶 構造が変化したことに由来している。このほかにもアゾ ベンゼン,3) スチルベン,4) スピロピラン5)などからなる 有機結晶において, 固体中でフォトクロミズムが進行し 結晶構造変化を誘起する系が知られている. 光応答性を 示す結晶材料では, 結晶構造の変化に伴い結晶外形の

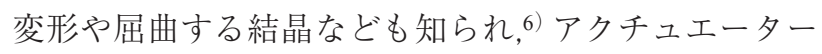
への応用に期待がもたれている.しかし, 分子デザイン のバリエーションは多くはなく, 光異性化挙動のよく知 られているフォトクロミック分子が導入された結晶の 報告が多くを占めている. すなわち, 光照射により分子 内／間で生じる化学結合を変化させ, 結晶構造とその物 性を切り替える分子デザインが多い.

\section{2. 金原子間相互作用とその光応答特性}

金原子間相互作用は光励起によってその結合の強さ 日本結晶学会誌 第 57 巻 第4号 (2015) 
が増強し，金原子間距離が短くなることが知られている ため, 金錯体は光応答性材料への応用が可能と言える.7) 図2に金原子間相互作用の形成の模式図, また対応する エネルギー準位，励起状態における変化をまとめた，金 原子間相互作用は, 非共有結合性の相互作用である分 散力の一種である.2つの金原子が, 約 $3.5 \AA$ (金原子の ファンデルワールス半径の約 2 倍に相当）よりも近づい た場合に，金原子間における吸引的な相互作用が顕著に なる，金原子の顕著な相対論効果によって，通常のファ ンデルワールスカよりも結合の力は大きく, 水素結合 と同程度に達すると言われている，配位子の種類にも よるが, 金錯体の HOMOは一般に, 金原子の $5 \mathrm{~d}_{\mathrm{z}^{2}}$ 軌道に よって形成されている [図2 $(\mathrm{i})]$. 溶液中や結晶格子内 で, 金錯体が金原子間相互作用を形成するときHOMOが 分裂し, $d \sigma$ と $d \sigma^{*}$ 軌道が新たに形成される [図2 (ii)]. これら新しく生成した軌道は, それぞれ結合性および反 結合性の性質をもっている。このとき, HOMOは反結合

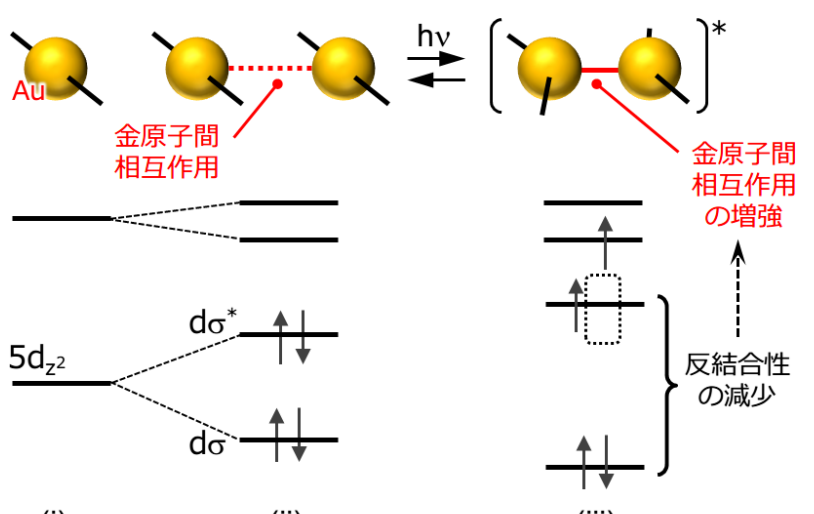

(i)

(ii)

(iii)

図2 金原子間相互作用とその簡略化した軌道準位の模 式図. (Schematic representation of aurophilic bonds and their simplified orbital levels.) 金原子間相互作 用の形成は軌道の分裂を誘起し, 結合性軌道 $\mathrm{d} \sigma$ と反結合性軌道 $\mathrm{d} \sigma *$ が形成される (ii). また, これ を励起すると, 反結合性の $\mathrm{d}^{*}$ *軌道 (HOMO) から 1 電子遷移し金原子間相互作用は増強する (iii).

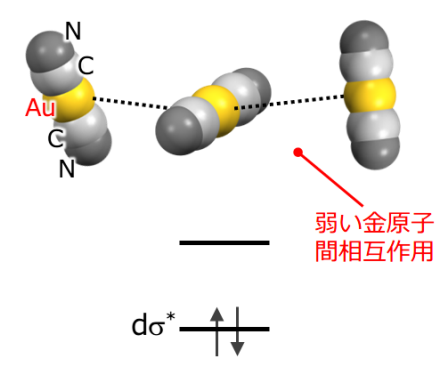

$\left[\mathrm{Au}(\mathrm{CN})_{2}^{-}\right]_{3}$ in $\mathrm{H}_{2} \mathrm{O}$

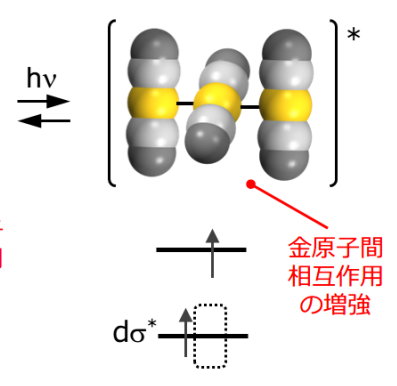

(寿命 : $2.0 \mathrm{~ns}$ )
図3 $\left[\mathrm{Au}(\mathrm{CN})_{2}^{-}\right]_{3}$ 錯体の金原子間相互作用が励起状 態で増強される模式図. (Schematic representation of the relaxation pathway upon photoirradiation of $\left[\mathrm{Au}(\mathrm{CN})_{2}{ }^{-}\right]_{3}$ complexes. $)$ 詳細は文献7)を参照.
性の $\mathrm{d} \sigma *$ 軌道となる $[$ 図2 (ii)]. 金原子間相互作用を形 成する前と比べ, HOMO はエネルギー的に不安定化し, その結果バンドギャップが小さくなる，そのため，金錯 体が金原子間相互作用を形成すると, 吸収や発光波長 の長波長化が観測されることが一般的である.7)

さらに，金原子間相互作用を形成した金錯体は励起 状態において興味深い挙動を示すことが知られている。 金原子間相互作用を形成した金錯体を光励起すると, HOMO の電子が 1 電子励起される $[$ 図 2 (iii)]. 基底状態 においてこの電子は, 反結合性を示していた。つまり, この電子が光励起されることで形成する励起状態では, 金原子間の反結合性が減少することになる，すなわち 結合性が上昇するため, 金原子間に引力が働く，その結 果, 励起状態において金原子間距離が短くなり, 金原子 間相互作用が増強することが知られている，励起状態に 拈ける金原子間相互作用の増強は, 理論計算によって詳 細に検討がなされ複数の論文で報告されている, 8 そ) その 一方で, 光励起に伴う金原子間相互作用の増強が実験 的に観測された例はほとんどない. 例えば理化学研究所 の田原教授らのグループは, $\left[\mathrm{Au}(\mathrm{CN})_{2}{ }^{-}\right]_{3}$ 錯体の水溶液 中での時間分解発光スペクトル測定を行い, $420 \mathrm{~nm}$ に寿 命 $2.0 \mathrm{~ns}$ の励起種由来の発光を観測した（図3). 筆者ら はこの励起種が, 励起状態に扔いて $\left[\mathrm{Au}(\mathrm{CN})_{2}{ }^{-}\right]_{3}$ 錯体の 金原子間相互作用が増強された過渡種であると報告して いる. さらにごく最近になって, 高エネルギー加速器研 究機構の足立教授らも, 放射光を用いて $\left[\mathrm{Au}(\mathrm{CN})_{2}{ }^{-}\right]_{3}$ 錯体の水溶液の励起状態を詳細に調查し, 金原子間相 互作用の形成や増強過程のダイナミクスについて報告 している.9）しかし $\left[\mathrm{Au}(\mathrm{CN})_{2}{ }^{-}\right]_{3}$ 錯体では, 励起状態の 過渡種として金属間結合の増強が観測されており, 光照 射をやめると金属間結合が増強されていない元の基底 状態に戻ってしまう，その他の金属錯体でもこれと同様 の現象が報告されている. 白金やロジウム, イリジウム 加なる金属錯体も光励起によって過渡的に金属間相 互作用が強くなることが知られているが, 10$)$ 光励起をや めるとその結合の増強は保持されない.これは多くの場 合, 分子が自由に動ける溶液中に打いて, 金属間相互作 用の増強が観測されていることが 1 つの要因であると言 える，そんな中われわれは最近，金(I)イソシアニド錯 体1（図4）が, 光励起によって金原子間相互作用を増強 させ, 金原子間相互作用が増強された新しい結晶相へ転 移することを見出したので, 詳しく解説する.

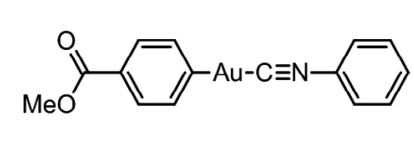

1

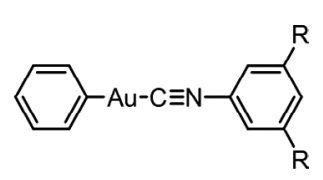

2: $\mathrm{R}=\mathrm{H} ; \mathbf{3}: \mathrm{R}=\mathrm{CH}_{3}$
図4 錯体 $\mathbf{1} \sim \mathbf{3}$ の構造.（Structures of $\mathbf{1} \sim \mathbf{3}$.) 


\section{3. 金イソシアニド錯体1の光誘起結晶相転移}

\section{1 アリール金イソシアニド錯体}

われわれは, 2008 年頃から金イソシアニド錯体の発 光性メカノクロミズムに関し, 精力的に研究を行ってき

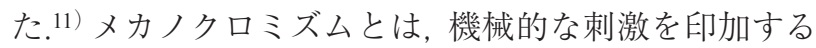
ことで固体の発光色が変化する現象のことである. ${ }^{12)}$ 発 光の変化は, 機械的な刺激の印加によって結晶構造が 変化し分子間相互作用のパターンが切り替わることに 由来している，われわれの研究室では, 数多くのアリー ル金イソシアニド錯体誘導体が発光性メカノクロミズ ムを示し, 機械的刺激の印加によって発光特性の異な る新しい結晶構造へ切り替わることを報告している.13) 特に近年, われわれの合成した金イソシアニド錯体 2 や $\mathbf{3}$ が, 機械的刺激をトリガーとして単結晶一単結晶相転 移を示し発光特性が変化することを報告している.14) 機 械的刺激は一般的に結晶の外形や結晶内部の秩序ある 分子配列を乱してしまうような外部刺激である。しかし $\mathbf{2}$ や 3 に対しては, 単結晶間の相転移を誘起できるため, 大変珍しい現象であり過去に報告例もなかった。一方錯 体1においては, 強度の強い紫外光を照射することで単 結晶一単結晶相転移を示すことを見出した. 種々の測定 の結果, 励起状態における金原子間相互作用の増強が, この結晶相転移の鍵であることが明らかとなった. ${ }^{15)}$ 本 稿では, 1 の光誘起結晶相転移とそのメカニズム, およ びこれに伴う結晶のジャンプ (Photosalient効果) に関し 詳細に述べる。

\section{2 金イソシアニド錯体1の紫外光照射に伴う結晶相 転移}

錯体 1 は, 暗所での再結晶により弱い青色発光単結 晶を得ることができる(これを1Bと呼ぶ, 図5左).1B の発光の絶対量子収率 $\Phi_{\mathrm{em}}$ は, $2.2 \%$ であった。励起光 を $370 \mathrm{~nm}$ として測定した発光スペクトルを図6に示 す (青実線)。発光極大波長 $\left(\lambda_{e m, m a x}\right)$ は, $448 \mathrm{~nm}$ に観測 された. $450 \mathrm{~nm}$ の発光の減衰プロファイルは, 三次で フィッティングすることができた. 平均の発光寿命 $\tau_{a v}$ は, $34.2 \mu \mathrm{s}$ であった. $590 \mathrm{~nm}$ の発光をモニターした1B
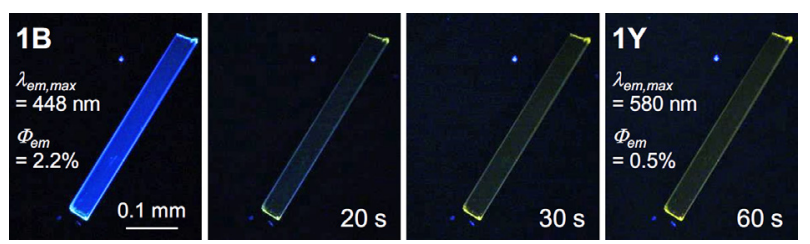

図5 錯体 1B の $1 Y$ への光誘起単結晶 - 単結晶相転移. (A series of photographs of the SCSC phase transition from 1B to $\mathbf{1 Y}$ induced by strong photoirradiation (367 $\mathrm{nm}$, approx. $100 \mathrm{~mW} \cdot \mathrm{cm}^{-2}$ ) taken under excitation at $365 \mathrm{~nm}$.)
の励起スペクトルを青点線で示しており，371 nmに極大 をもち, $400 \mathrm{~nm}$ 以上の可視域ではほとんど吸収は見られ なかった。

1Bの単結晶を作製し, X線結晶構造解析を行った。 空 間群は, $P \overline{1}$ であった $\left[R_{1}=8.67 \%, w R_{2}=24.96 \%, \mathrm{GOF}\right.$ $=1.106, a=7.381(2) \AA, b=11.755(2) \AA, c=15.940(3) \AA$, $\alpha=102.912(5)^{\circ}, \beta=92.025(5)^{\circ}, \gamma=100.595(5)^{\circ}, Z=4$, $V=1320.8(4) \AA^{3}, d=2.189 \mathrm{~g} \cdot \mathrm{cm}^{-3}$ ] (図 7). 1Bの信頼度 因子 $\left(R_{1}\right.$ や $\left.w R_{2}\right)$ は比較的精度が悪いが, この要因は結 晶化やX線回折測定の際に室内光に含まれる微弱な紫 外線の照射によって, 結晶の一部が $1 Y$ へ相転移したた めだ考えられる。また，X線結晶構造解析のデータか らは, 溶媒の包摂を示すような残存電子密度は観測され なかった，溶媒を包摂していないことは, 元素分析, 熱 分析, ${ }^{1} \mathrm{H}$ NMR 測定の結果からも支持されている. 結晶

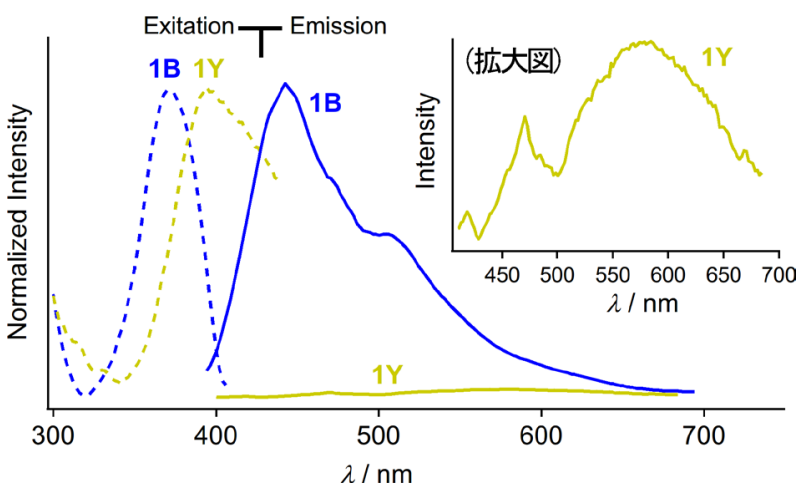

図6 1Bと 1Y の励起・発光スペクトル. (Excitation and emission spectra of 1B and 1Y.) 青 · 黄色点線 : 1B (モニター波長：450 nm) と 1Y（モニター波長： $590 \mathrm{~nm}$ ) の励起極大強度で規格化した励起スペク トル. 青・黄色実線：1B（励起波長：370 nm）と 1Y（励起波長：390 nm) の発光スペクトル（吸収 スペクトルの強度を基に規格化). Inset：1Yの発 光スペクトルの拡大眓. 編集部注 : カラーの眓は オンライン版を参照下さい。

a)
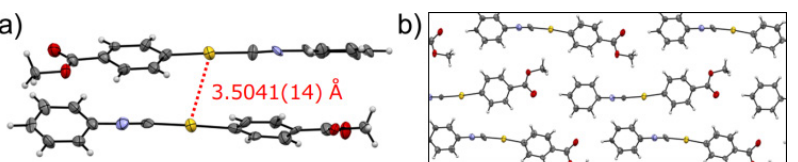

c)

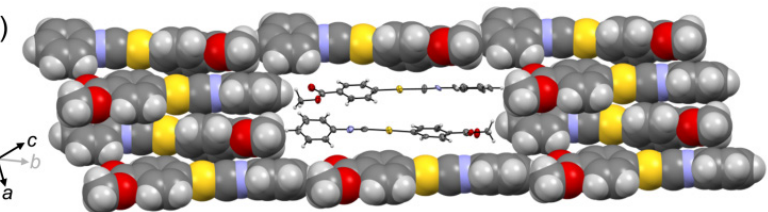

図7 1Bの単結晶構造. (The single-crystal structure of 1B.）a）ダイマーユニットのORTEP図.b）金原 子間結合の水平方向から見たパッキング構造の ORTEP図. c) 金原子間結合の垂直方向から見た パッキング構造の CPKモデル図. 中心のダイマー のみ ORTEP図で表記.

日本結晶学会誌 第 57 巻 第 4 号 (2015) 
内には, 結晶学的に独立した $2 つ の$ 錯体 1 がパッキング している. 分子内の 2 つベンゼン環の 2 面角は, それ ぞれ $26.76^{\circ}$ および $56.04^{\circ}$ であった。 この2つの分子が, Head-to-tail型のダイマーユニットを形成している.ダイ マー内の分子間の金原子間距離は, 3.5041（14）凡であ り，比較的弱い金原子間相互作用を形成していることが わかった。このダイマーはさらに積層し一次元カラム構 造を構築し, 隣接するカラムとシート状に配列し結晶構 造を作っている。

1Bに対して, 強い紫外光を照射すると発光色が徐々

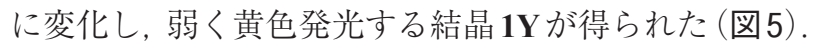
このとき用いた光源は, 高圧水銀灯であり, 発光極大が $367 \mathrm{~nm}$, 結晶表面での光の強度は約 $100 \mathrm{~mW} \cdot \mathrm{cm}^{-2}$ であ る. $60 \mathrm{~s}$ 間の光照射によって 1Bの青色発光は徐々に変 化し非常に弱い黄色発光へ変化した（図5). 光照射後に 得られる結晶を $1 Y$ と呼ぶことにする. 光照射に伴い, 結晶は黄色に変色したが, 外観の透明性は保持されて いた。減光フイルターを用い, 紫外光強度を $5 \mathrm{~mW} \cdot \mathrm{cm}^{-2}$ 程度まで減少させても, 1Bの発光色は変化するが, 10 分 以上の光照射時間を要する.1Yの発光は, 非常に弱 く $\Phi_{\mathrm{em}}$ は, $0.5 \%$ であった. 発光スペクトルの発光極大 $\lambda_{\text {em, } \max }$ は580 nmである (図6黄色実線). 1Bの発光極大 に比べ, $132 \mathrm{~nm}$ の長波長シフトを示した。また励起スぺ クトル (図6黄色点線)の極大波長も, 光照射によって $23 \mathrm{~nm}$ の長波長シフトを示した. $580 \mathrm{~nm}$ の発光減衰プロ ファイルは二次でフィッティングでき, $\tau_{a v}$ は $0.685 \mu \mathrm{s}$ で あった。これは, 1Bの $\tau_{a v} よ り も 50$ 倍程度短い。

1YのX線回折測定の結果, 1Bは光照射によって単結 晶一単結晶相転移を示していることが明らかとなった。 われわれは, あらかじめ単結晶構造解析に成功した1B の結晶を複数用意し, 上記条件で紫外光を照射し $1 Y$ と した後, 再びX線回折測定を試みた。その結果, 単一の 結晶を用いても, 光照射の前後で1Bと 1 Y がともに単 結晶性を保持していることが再現性良く確かめられた。 単結晶 $1 \mathbf{Y}$ の空間群は $P \overline{1}$ であった $\left[R_{1}=5.42 \%, w R_{2}=\right.$ $13.30 \%, \mathrm{GOF}=1.045, a=6.0552(5) \AA, b=7.0297(6) \AA$, $c=15.969$ (2) $\AA, \alpha=96.315(3)^{\circ}, \beta=93.979(3)^{\circ}, \gamma=$ $\left.90.279(3)^{\circ}, Z=2, V=673.9(1) \AA^{3}, d=2.145 \mathrm{~g} \cdot \mathrm{cm}^{-3}\right]$ (図8). 残存電子密度の強度は十分に低く, 溶媒の包摂 はない. 元素分析, 熱分析, ${ }^{1} \mathrm{H}$ NMRの結果もこれを支 持している.1Yは, Head-to-tail型のダイマー構造を形成 しており, さらにこれらが積層したカラム構造の配列に よりシート構造を作っていた，以上の結晶構造の特徴は $1 \mathrm{~B}$ と類似しているが, 以下の 2 点において大きく異なっ ている. 第 1 に, 分子が大きく屈曲している. 分子内の 2つのベンゼン環を連結する金イソシアニド部位が1Bで はほぼ直線である一方，1Yでは大きく屈曲している。ま た2点目として, 金原子間距離の減少が挙げられる.1Y 日本結晶学会誌 第 57 巻 第 4 号 (2015)
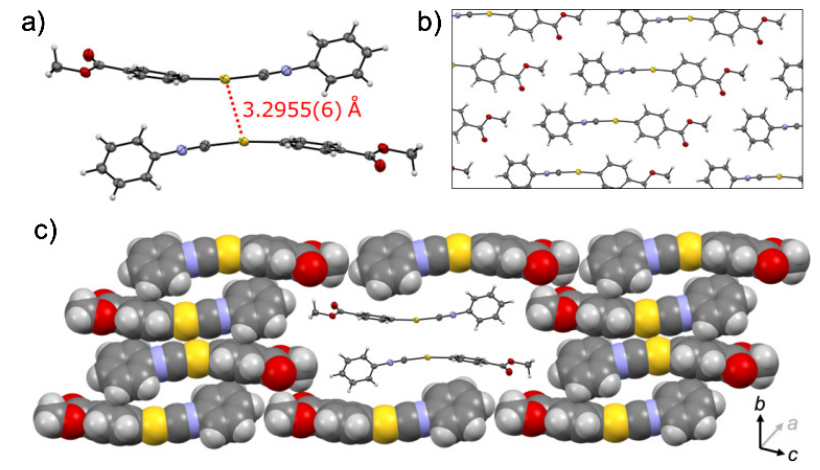

図8 1Y の単結晶構造. (The single-crystal structure of 1Y.) a) ダイマーユニットのORTEP図. b) 金原子間結 合の水平方向から見たパッキング構造の ORTEP 図. c) 金原子間結合の垂直方向から見たパッキ ング構造のCPKモデル図. 中心のダイマーのみ ORTEP図で表記.

の金原子間距離は, 3.2955 (6) ^であり，1Bに対して約 $0.2 \AA$ 減少した。つまり結晶相転移によって金原子間相 互作用がより増強しており，発光の長波長シフトの要因 であると言える. また, 分子の屈曲は, エネルギー的に 不利と考えられるが，これは比較的結合力の高い分子間 相互作用である金原子間相互作用の形成によって, 補償 されていると考えられる。

\section{3 励起状態における金原子間相互作用の増強を利用 した光誘起結晶相転移}

われわれは, 錯体 1 の光誘起結晶相転移 $(\mathbf{1 B} \rightarrow \mathbf{1 Y})$ に 関し種々のコントロール実験を行い, この現象が $1 \mathrm{~B}$ 結 晶の光励起が必須の現象であることを確かめた. 始めに, 結晶を加熱しても $1 \mathrm{~B} \rightarrow 1 \mathrm{Y}$ の相転移が進行しないこと を確かめた。1Bと1Yを大気下で加熱すると, ともに約 $120^{\circ} \mathrm{C}$ で分解し, その過程で発光色の变化などは観測さ れなかった. DSC 測定を行ったところ, それぞれ $121^{\circ} \mathrm{C}$, $120{ }^{\circ} \mathrm{C}$ で分解に対応する吸熱ピークが観測され，そのほ かにはいっさいピークが観測されなかった.1B $\rightarrow 1 Y$ の 光誘起結晶相転移の過程をサーモグラフィーカメラで観 測すると, 光照射による温度上昇は $2^{\circ} \mathrm{C}$ 以下であった。 以上の実験データより, 加熱によって結晶相転移が進 行しないことが確かめられた. 次に光源として可視光で ある $435 \mathrm{~nm}\left(200 \mathrm{~mW} \cdot \mathrm{cm}^{-2}\right)$ を用いた場合に, 光誘起結 晶相転移が進行しないことも確かめた。 励起スペクトル より，この波長領域で1B は吸収をもたないことがわかっ ている.つまりこれらの結果は, 1B $\rightarrow$ 1Y の光誘起結晶 相転移が $1 \mathrm{~B}$ の光励起状態を経由し進行していることを 示している.

種々の条件で行った量子化学計算に基づいて, 1B $\rightarrow 1 Y$ の光誘起結晶相転移が, 励起状態における金原子 間相互作用の増強により誘起されていることを明らかに した，結晶全体の量子化学計算は, 計算コストが高すぎ 
るため, われわれは1Bの単結晶構造から再近接したダ イマーを抽出し，このモデル構造のDFT計算 (PBEPBE/ SDD）を種々条件で行った。まずは一点計算を行い, 1 B ダイマーの分子軌道を求めた。 図 $9(\mathrm{i})$ 下に示すように, ダイマーのHOMOには金原子間にノードが分布してお り, 反結合性の性質を有していることを示している。こ れは図2 (ii) に示すような, 一般的に金原子間相互作用 を形成した際に見られる分子軌道の特徵を, 1B も有し ていることを示している. 次に同じ1Bのダイマーを初期 構造とし, 真空条件で全体のスピンをトリプレットに指 定して構造最適化し, 1B ダイマーの3 重項励起状態の 最適化構造のモデル $1 T_{\text {Opt }}$ を得た. 1Bのダイマーから得 られた最適化構造 1T Opt を図9(ii) に示す. Head-to-tail型 のダイマー構造は維持されているものの, 分子内のベン ゼン環を連結している金イソシアニドユニットが大きく 屈曲している。またこれに伴い, 金原子間距離が $2.86 \AA$ に減少している。以上の結果より，1Bのダイマーユニッ 卜は, 光励起により 3 重項状態となると金原子間距離が 短くなり, 金原子間相互作用が増強することが明らかと なった，この要因は，図2で説明したように, 反結合性 のHOMOを占めていた電子の励起による金原子間相互 作用の増強に対応している。しかも $1 \mathbf{T}_{\mathbf{O p t}}$ の構造は, 1Y の結晶構造から抽出したダイマーの構造 [図9(iii)上）と 類似している。すでに述べたようにここで得られた計算 結果は, 単結晶構造から抽出したダイマー構造を初期構 造とし, 真空条件の量子化学計算により得られている. そのため, 1Bの結晶格子に束縛されたダイマー内でこれ とまったく同じ構造変化が起きることを主張できるもの ではない. しかし, 1Bの結晶格子のダイマー内では, 光 励起により金原子間相互作用が増強し, 1Yのダイマー と似た構造に変化するような相互作用が働きうることを

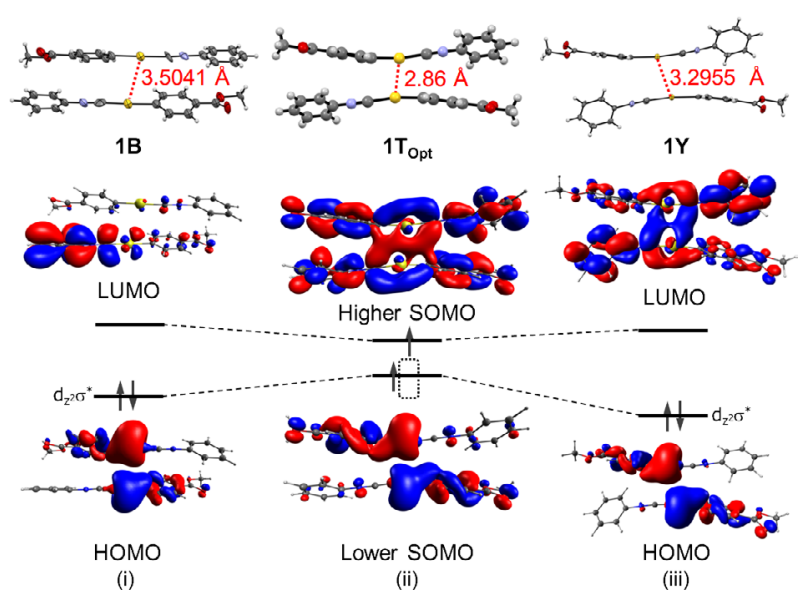

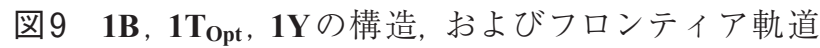
エネルギー準位図と対応する分子軌道の比較. (Comparison of the structures and frontier orbital levels and the corresponding molecular orbitals of 1B, 1T Opt, and 1Y.)
示している.以上より, 金原子間に働く吸引的な相互作 用によって1B全体の分子の再配列が進行し $1 Y$ 亿と光 誘起結晶相転移が進行したと考えている. 金属間の相互 作用を光照射によって増強させ, 結晶相転移を誘起した 例は過去に報告がない。

\subsection{Photosalient効果}

錯体 1 の光誘起結晶相転移のメカニズムの解明を試み ている過程で, この錯体がPhotosalient効果と呼ばれる興 味深い現象を示すことを見出した. Salient効果とは, 外 部刺激に誘起された結晶構造の変化に伴い結晶がジャ ンプする現象のことである(図 10). ${ }^{16)}$ Salient効果が起 こる要因は, 結晶に対して特定の外部刺激を与えるこ とで結晶内部の分子配列が変化し, 結晶内にひずみが 生じることに由来する。このひずみをある瞬間一気に 外部にリリースすることで, 瞬発的に機械的な力が生 じ結晶が宙を舞う。外部刺激に温度変化を用いた場合 にThermosalient効果, 光を用いた場合にPhotosalient効 果と呼ばれる. Salient効果を示す有機結晶はこれまでに 20 例足らずしか知られておらず,17)珍しい現象である. 中でも Photosalient効果は例が少なく, 錯体 $\mathbf{1}$ 以前には Photosalient効果を示した結晶の報告は, 筆者らの知る 限り4例しかない.

錯体 1 は, 約 $400 \mathrm{~mW} \cdot \mathrm{cm}^{-2}$ の強い紫外光 $(367 \mathrm{~nm})$ を 照射した際に結晶がジャンプする Photosalient効果を示 した，図11に示すように, 約 $400 \mathrm{~mW} \cdot \mathrm{cm}^{-2}$ の紫外光を

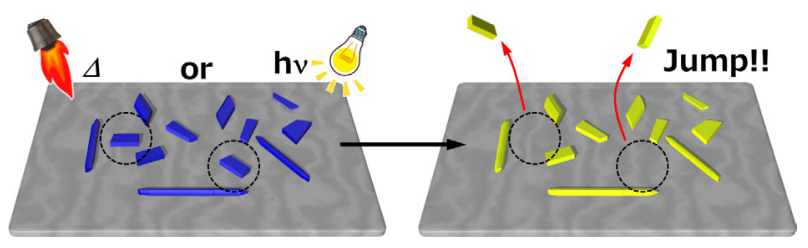

図10 Salient効果の模式図. (Schematic representation of salient effect.)
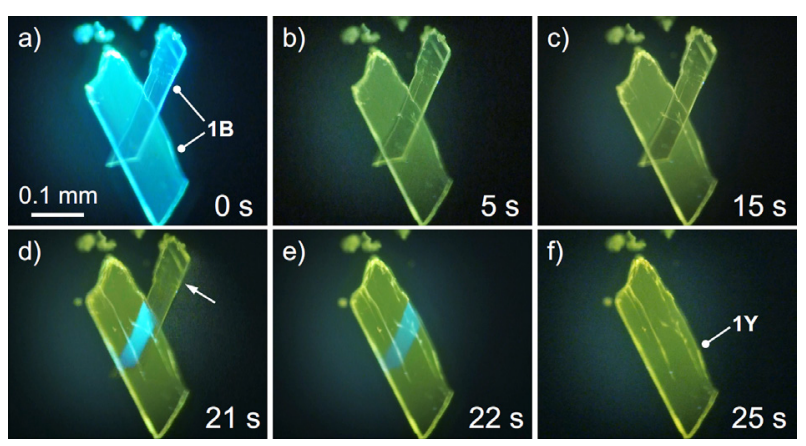

図11 錯体 1 のPhotosalient効果の写真. (A series of photographs of the photosalient effect of $\mathbf{1 B}$ through the transformation into $\mathbf{1 Y}$ induced by strong photoirradiation (367 $\mathrm{nm}$, approx. $\left.400 \mathrm{~mW} \cdot \mathrm{cm}^{-2}\right)$.) ジャンプする直前の結晶をd)の矢印で示す.

日本結晶学会誌 第 57 巻 第 4 号 (2015)

(2015) 
1Bの結晶に照射すると, 5 秒程度で発光の色が青から黄 色に変化した（図11a,b). 発光色の変化は, 結晶表面 で1Bから 1Yへの結晶相転移が進行していることを示し ている，さらに光照射を続けるとひびが入り（図11c）, 21 秒後に図11dの矢印で示した結晶がジャンプした. 残 念なことに錯体 1 に関しては，すべての1B結晶が上記 の条件でPhotosalient効果を示すわけではない. ジャン プする1B結晶は全体のわずか $1 \%$ のであった。しか し, 全体の $80 \%$ の結晶で紫外光照射によってひびが入

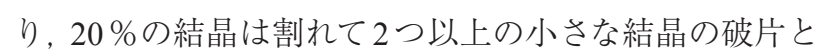
なった.このような挙動の違いは, 同じバッチ内で再結 晶された結晶間においてさえ, 結晶性の程度に違いがあ ることを示している. 既報のSalient活性分子も, 結晶の ジャンプだけでなく, 結晶の外形にひびが入り, あるい は結晶が割れる現象が観測されている. 16) 1 の Photosalient 効果は, 分子間相互作用の一種である金原子間相互作 用が光励起によって増強されることにより誘起されてい る. 既報のPhotosalient活性分子では, ジアリールエテン やオレフィンの光環化反応によって結晶内の分子の共 有結合が組み替り, その結果結晶全体の相転移が誘起 され, Photosalient効果を示している。一方，1のように共 有結合の形成や切断が起こることなくSalient効果を示 す系はこれまでに報告されていない.

1がPhotosalient を示す前後の結晶構造（1Bと1Y）の 特徵は, Salient活性な分子に見られる典型的な結晶構造 とよく一致している。ニューヨーク大学アブダビ校の Naumovらは, Salient効果に関してきわめて精力的な研 究を近年展開している. ${ }^{16)}$ 彼らは, Salient効果のメカニ ズムや分子レベルの配列・相互作用との関連を包括的に 考察すべく, 既報の Thermosalient 活性な分子の再調査 を徹底的に行い, 単結晶 $\mathrm{X}$ 線構造解析, 熱分析, 八イス ピードカメラを用いたジャンプ現象の詳細な観察結果を 報告している。これらを基に, Salient活性分子に共通す る結晶構造の特徵を以下のようにまとめている. Salient 効果が起こる前後に結晶相転移が起こるが, その前後の 結晶構造は互いに非常によく似ており, 分子の空間的な 相対位置がわずかにしか変わらない.これは一般にマル テンサイト変態と呼ばれる。 それゆえ, 空間群は変わら ず, 1 分子当たりの単位胞体積 $V / Z$ の変化 $\Delta_{V / Z}$ も非常に 小さく, すべての報告例で $\Delta_{V I Z}<25 \AA^{3}$ を満たす。また, 特定の方向の格子長がわずかに伸長し, その他の格子長 がわずかに収縮するという異方的な結晶格子サイズの変 化が生じる. その結果, 分子配列変化に伴い局所的に発 生する微小なひずみが, 結晶内で全体として打ち消しあ うことなく外部に放出されると提案している. 錯体 1 も Naumovらが考察したSalient活性分子に共通の結晶構造 の特徴をすべて満たしている，空間群は $P \overline{1}$ で不変であ り, $\Delta_{V / Z}=6.8 \AA^{3}$ と非常に小さい. また, 異方的な格子軸 日本結晶学会誌 第 57 巻 第 4 号 (2015)
長の変化を示す。錯体 1 は, 分子内／間で生じる化学結 合の変化を伴わない初めてのPhotosalient活性な分子で あるが, Naumovらが考察したSalient効果を示す結晶の 必要条件の多くを満たしており, 彼らの考察の一般性を 裏付ける1つの例である。

\section{4. おわりに}

本稿では, 金イソシアニド錯体 1 の金原子間相互作用 の増強を伴う光誘起単結晶 - 単結晶相転移に関し概説 した，相転移の前後で金原子間距離が短くなり，金原子 間相互作用が増強され, 明確な発光スペクトルの長波長 化が観測された，光照射に伴う金属間結合の増強をトリ ガーとして, 結晶構造相転移を導いた初めての例であ る. また, より光密度の高い紫外光を用い錯体 1Bを励 起すると, 結晶構造相転移に伴い結晶がジャンプする Photosalient効果を示した. 錯体1はPhotosalient効果を 示した 5 例目の分子であり, 共有結合の形成や切断を含 まない初めての例である。一般的に, 光応答性の結晶材 料をデザインする際には, アゾベンゼンやジアリールエ テンのようなフォトクロミック分子からの誘導が広く適 用されている。本稿で紹介したように, 金属間相互作用 において特有な光応答性を利用することで，今後新規な 光応答性の固体材料の開発が進展すると考えられる.

\section{文 献}

1) (a) J. Zhang, Q. Zou and H. Tian: Adv. Mater. 25, 378 (2013); (b) M. Irie, T. Fukaminato, K. Matsuda and S. Kobatake: Chem. Rev. 114, 12174 (2014).

2) S. Kobatake, S. Takami, H. Muto, T. Ishikawa and M. Irie: Nature 446, 778 (2007).

3) O. S. Bushuyev, A. Tomberg, T. Friscic and C. J. Barrett: J. Am. Chem. Soc. 135, 12556 (2013).

4) J. W. Chung, S.-J. Yoon, B.-K. An and S. Y. Park: J. Phys. Chem. C 117, 11285 (2013).

5) S. Iyengar and M. C. Biewer: Cryst. Growth Des. 5, 2043 (2005).

6) N. K. Nath, L. Pejov, S. M. Nichols, C. Hu, N. Saleh, B. Kahr and P. Naumov: J. Am. Chem. Soc. 136, 2757 (2014).

7) (a) A. L. Balch: Gold Bull. 37, 45 (2004); (b) P. Pyykko: Angew. Chem., Int. Ed. 43, 4412 (2004); (c) V. W. Yam and E. C. Cheng: Chem. Soc. Rev. 37, 1806 (2008).

8) (a) G. Cui, X. Y. Cao, W. H. Fang, M. Dolg and W. Thiel: Angew. Chem., Int. Ed. 52, 10281 (2013); (b) H. H. Patterson, S. M. Kanan and M. A. Omary: Coord. Chem. Rev. 208, 227 (2000).

9) (a) M. Iwamura, K. Nozaki, S. Takeuchi and T. Tahara, J. Am. Chem. Soc. 135, 538 (2013); (b) K. H. Kim, J. G. Kim, S. Nozawa, T. Sato, K. Y. Oang, T. W. Kim, H. Ki, J. Jo, S. Park and C. Song: Nature 518, 385 (2015).

10) (a) K. Haldrup, T. Harlang, M. Christensen, A. Dohn, T. B. van Driel, K. S. Kjaer, N. Harrit, J. Vibenholt, L. Guerin, M. Wulff and M. M. Nielsen: Inorg. Chem. 50, 9329 (2011); (b) R. M. van der Veen, C. J. Milne, A. El Nahhas, F. A. Lima, V. T. Pham, J. Best, J. A. Weinstein, C. N. Borca, R. Abela, C. Bressler and M. Chergui: Angew. Chem., Int. Ed. 48, 2711 (2009).

11) H. Ito, T. Saito, N. Oshima, N. Kitamura, S. Ishizaka, Y. Hinatsu, 
M. Wakeshima, M. Kato, K. Tsuge and M. Sawamura: J. Am. Chem. Soc. 130, 10044 (2008)

12) (a) Y. Sagara and T. Kato: Nat. Chem. 1, 605 (2009); (b) A. L. Balch: Angew. Chem. Int. Ed. 48, 2641 (2009); (c) C. Jobbágy and A. Deák, Eur. J. Inorg. Chem. 2014, 4434 (2014).

13) (a) K. Kawaguchi, T. Seki, T. Karatsu, A. Kitamura, H. Ito and S. Yagai: Chem. Commun. 49, 11391 (2013); (b) T. Seki, T. Ozaki, T. Okura, K. Asakura, A. Sakon, H. Uekusa and H. Ito: Chem. Sci. 6, 2187 (2015).

14) (a) T. Seki, K. Sakurada and H. Ito: Angew. Chem., Int. Ed. v52, 12828 (2013); (b) H. Ito, M. Muromoto, S. Kurenuma, S. Ishizaka, N. Kitamura, H. Sato and T. Seki: Nat. Commun. 4, 2009 (2013).

15) T. Seki, K. Sakurada, M. Muromoto and H. Ito: Chem. Sci. 6, 1491 (2015).

16) (a) N. K. Nath, M. K. Panda, S. C. Sahoo and P. Naumov: CrystEngComm 16, 1850 (2014) ; (b) S. C. Sahoo, M. K. Panda, N. K. Nath and P. Naumov: J. Am. Chem. Soc. 135, 12241 (2013).

17) (a) M. C. Etter and A. R. Siedle: J. Am. Chem. Soc. 105, 641 (1983); (b) I. Colombier, S. Spagnoli, A. Corval, P. Baldeck, M. Giraud, A. Léaustic and P. Yu: Mol. Cryst. Liq. Cryst. 431, 495 (2005).

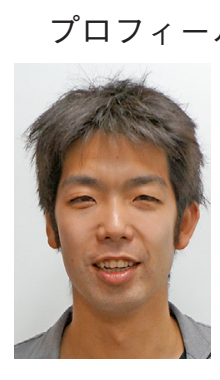

関 朋宏 Tomohiro SEKI

北海道大学大学院工学研究院 - フロンティア化 学教育研究センター

Faculty of Engineering, Frontier Chemistry Center, Hokkaido University

干 060-8628 北海道札幌市北区北13 条西 8 丁目

Kita 13 Nishi 8 Kita-ku, Sapporo, Hokkaido 0608628, Japan

e-mail: seki@eng.hokudai.ac.jp

最終学歴：千葉大学大学院

専門分野: 有機化学, 超分子化学, 機能性材料 化学

現在の研究テーマ: 刺激応答性発光材料の研究

趣味：山, スポーツジム

伊藤 肇 Hajime ITO

北海道大学大学院工学研究院 . フロンティア化

学教育研究センター

Faculty of Engineering, Frontier Chemistry Center, Hokkaido University

干 060-8628 北海道札幌市北区北 13 条西 8 丁目

Kita 13 Nishi 8 Kita-ku, Sapporo, Hokkaido 0608628, Japan

e-mail: hajito@eng.hokudai.ac.jp

最終学歴: 京都大学大学院

専門分野：有機金属化学, 錯体化学

現在の研究テーマ：銅触媒による不斉ホウ素化

反応, 刺激応答性金錯体の研究 